\title{
Ectomycorrhizal fungal community associated with autochthonous white poplar from Serbia
}

\author{
Marina Katanić (1), Tine \\ Grebenc $^{(2)}$, Saša Orlović (1), \\ Milan Matavuly ${ }^{(3)}$, Branislav \\ Kovačević( ${ }^{(1)}$, Marko Bajc ${ }^{(2)}$, \\ Hojka Kraigher ${ }^{(2)}$
}

\begin{abstract}
We analyzed the community of ectomycorrhizal fungi of an autochthonous white poplar (Populus alba L.) stand in the Kovilj-Petrovaradin marshes (Serbia), and examined its seasonal dynamics. Ectomycorrhizal types were identified by combining morphological and anatomical descriptions with molecular methods (sequencing of ITS region of ribosomal DNA). In two seasons, 20 ectomycorrhizal types were recorded, from which 11 types were identified to the species level, six were determined to the genus level, two types were determined to the family level and one type remained unidentified. Number of ectomycorrhizal types, number of fine roots, percentage of vital mycorrhizal roots, diversity indexes and abundance of exploration types did not differ significantly between autumn and spring. During both seasons, the most abundant types were: Entoloma sp., Tuber maculatum, Cenococcum geophilum, Tuber rufum and Peziza sp. Due to the high variation of the ectomycorrhizal types-based Shannon-Weaver diversity index in poplar stands, and the fact that poplars form dual mycorrhizal association, this index is not recommended as a reliable index for bioindication in poplar.
\end{abstract}

Keywords: Ectomycorrhiza, Populus alba, Diversity, Nature Reserve, Seasonal Dynamics, Morphological-Anatomical Characterization, Molecular Identification

has rarely attracted the interest of researchers, several prominent ECM species are thoroughly studied in poplars, in particular in white poplar (Populus alba L.), including the most expensive white truffle (Tuber magnatum Pico - Angelini \& Granetti 1995).

Seedlings colonized with compatible ECM fungal species and strains are favored in making contacts with water and nutrients, as well as with other organisms in the soil (Kraigher 1996). In addition to the increased nutrient uptake, mycorrhizas offer numerous other benefits to symbiontic tree species, such as enhanced plant efficiency in absorbing water, reduced fertilization and irrigation requirements, increased drought tolerance, increased pathogen resistance, protection against damage from heavy metals and other pollutants, mitigation of various plant stresses, improvement of seedling growth and survival, and
(1) University of Novi Sad, Institute of Lowland Forestry and Environment, Antona Cehova 13, 21000 Novi Sad (Serbia); (2) Slovenian Forestry Institute, Večna pot 2, 1000 Ljubljana (Slovenia); (3) European University, Faculty of Pharmacy, Trg mladenaca 5, 21000 Novi Sad (Serbia)

@ Marina Katanić (marinakatanic44@gmail.com)

Received: Jun 04, 2014 - Accepted: Jul 10, 2015

Citation: Katanić M, Grebenc T, Orlović S, Matavuly M, Kovačević B, Bajc M, Kraigher H (2015). Ectomycorrhizal fungal community associated with autochthonous white poplar from Serbia. iForest 9: 330-336. - doi: 10.3832/ifor1370-008 [online 2015-11-12]

Communicated by: Paola Mairota improvement of soil structure by the extramatrical hyphal network (Molina et al. 1992, Smith \& Read 2008, Quoreshi 2008).

The functional compatibility and stress tolerance of ectomycorrhizal types is species specific and depend on both partners. Therefore, information on the ECM community structure can provide valuable information about physiology of forest trees and functioning of forest ecosystems (Kraigher et al. 2007).

Limited data on ECM community in white poplar from natural stands are available and its seasonal dynamics remain unclear (Jakucs 2002). The aim of this work was to investigate the ECM community in a case study location represented by an autochthonous white poplar stand in the Special Nature Reserve "Kovilj-Petrovaradin marshes" in Serbia and to analyze seasonal changes in the community between spring and autumn.

\section{Materials and methods}

\section{Description of site and sampling}

ECM roots were isolated from soil samples collected in the Special Nature Reserve, close to Novi Sad, Serbia $\left(45^{\circ} 12^{\prime} \mathrm{N}\right.$, $19^{\circ} 58^{\prime} \mathrm{E}$, elevation $78 \mathrm{~m}$ a.s.l.). According to the results from a nearby measuring station (Rimski Šančevi), the average annual precipitation (1951-2010) was $625 \mathrm{~mm}$ and the average yearly temperature was $11.4^{\circ} \mathrm{C}$ (Stanojević 2012). Climate is a Dfa subtype of temperate continental climate with July and August as the warmest months (Republic Hydrometeorological Service of Ser- 
bia - http://www.hidmet.gov.rs/). The sampling site was occasionally flooded and the soil type was classified as fluvisol, loamy form (Katanić 2014). The sampling was performed in a naturally grown autochthonous white poplar (Populus alba L.) stand of 50-60 years old trees (100 trees ha-1) mixed with scarcely abundant Acer negundo L. and Robinia pseudoacacia L.

Five mature white poplar trees were randomly selected. Two soil samples per tree were taken in autumn (September 2009) and spring (March 2010) at a distance of about $1 \mathrm{~m}$ from the tree trunk. In total, ten soil samples were collected in each season. A soil corer of $274 \mathrm{ml}$ volume and reaching $18 \mathrm{~cm}$ depth was used for collecting standardized soil core samples (Kraigher 1999). Soil core samples were stored at $4{ }^{\circ} \mathrm{C}$ for up to one month. One day prior to analysis, soil samples were submerged in water and all fine roots were carefully washed from soil. Vital ECM root tips were separated from old, non-turgescent and non-mycorrhizal (ONN) root tips in water under a dissecting microscope. All fine root tip categories, including all identified types of $\mathrm{ECM}$, were counted as total number in individual soil core sample.

\section{Identification of ectomycorrhizae}

ECM types were identified by combining morphological and anatomical approach with molecular methods. Morphological and anatomical characteristics of each ECM root type were assessed by a binocular Olympus SZX 12 (light source: Olympus Highlight 3100, daylight filter) and DIC (Nomarski) microscope Olympus BX 51 (magnification 100-2000x) following Agerer (1991), Kraigher (1996), and ECM des- criptions published in Agerer (2008), Agerer et al. (2006), and Agerer \& Rambold (2014). Based on the presence and abundance of emanating elements, ECM types were also classified into the exploration types proposed by Agerer (2001).

Molecular identification was based on nucleotide sequencing of ITS regions (Internal Transcribed Spacer) in nuclear ribosomal DNA. This is considered the best molecular marker for fungi identification (Kõljalg et al. 2013). After DNA extraction from 5-20 root tips with a PlantDNeasy ${ }^{\circledR}$ Mini Kit (Qiagen, Hilden, Germany) from each ECM type, the ITS region was amplified using the ITS if and ITS 4 primer pair (Gardes \& Bruns 1993). DNA fragments were separated in and excised from agarose gel and purified with Wizard $^{\otimes}$ SV Gel and PCR Clean-up System ${ }^{\circledast}$ (Promega Corporation, Madison, WI, USA). Sequencing was performed commercially at Macrogen Inc. (Seoul, Rep. of Korea). Species, genus or family of ECM fungi were determined by comparing with the sequences deposited in the GenBank (http://www.ncbi.nlm.ni h.gov/genbank/index.html) and Unite (Abarenkov et al. 2010) databases.

\section{Data analysis}

Diversity indexes were calculated per sample and per site (i.e., by pooling the ECM community data) following the formulas given by Atlas \& Bartha (1981) and Taylor et al. (2000):

(i) Species richness $(d)=(S-1) / \log _{10} N$, where $S$ is the number of ECM types and $N$ is the number of all mycorrhizal tips;

(ii) Shannon-Weaver's diversity index $(H)=$ $C / N\left(N \log N-\Sigma n_{\mathrm{i}} \log n_{\mathrm{i}}\right)$, where $C=2.3$, $N$ is the number of all mycorrhizal tips

Tab. 1 - Identification of ectomycorrhizal (ECM) types from a mature white poplar (Populus alba L.) stand at the Special Nature Reserve Kovilj-Petrovaradin marshes (Serbia). Identifications are based on morphological-anatomical characters and nrITS DNA sequence comparison with the international nucleotide sequences databases. GenBank accession numbers are given for the analyzed ECM types. Exploration types were assessed after Agerer (2001).

\begin{tabular}{|c|c|c|}
\hline Ectomycorrhizal type & $\begin{array}{l}\text { Nucleotide database } \\
\text { accession number }\end{array}$ & Exploration type \\
\hline C. geophilum & HG937623 & short distance \\
\hline Genea verrucosa & HG937624 & short distance \\
\hline Hebeloma vaccinum & HG937625 & medium distance fringe subtype \\
\hline Hymenogaster tener & HG937626 & short distance \\
\hline Inocybe cf. meliolens & HG937629 & short distance \\
\hline Inocybe cf. rimosa & HG937627 & short distance \\
\hline Inocybe maculata & HG937628 & short distance \\
\hline Inocybe obsoleta & HG937630 & short distance \\
\hline Sebacina incrustans & HG937631 & short distance \\
\hline Tuber maculatum & HG937633 & short distance \\
\hline Tuber rufum & HG937632 & short distance \\
\hline Clavulina sp. & HG937634 & short distance \\
\hline Cortinariaceae sp. & HG937640 & short distance \\
\hline Entoloma sp. & HG937635 & medium distance smooth subtype \\
\hline Inocybe sp. & HG937636 & short distance \\
\hline Peziza sp. & HG937637 & contact \\
\hline Tomentella sp. 1 & HG937638 & short distance \\
\hline Tomentella sp. 2 & HG937639 & short distance \\
\hline Thelephoraceae sp. & HG937641 & short distance \\
\hline Unknown type KR & - & short distance \\
\hline
\end{tabular}

and $n_{\mathrm{i}}$ is the number of mycorrhizal tips of individual ECM type;

(iii) Evenness $(e)=H / \log S$, where $H$ is the Shannon-Weaver's diversity index and $S$ is the number of ECM types;

(iv) Equitability $(J)=H / H_{\max }$, where $H$ is the Shannon-Weaver's diversity index and $H_{\max }$ is the theoretical maximum $H$ assuming that each ECM type was equally abundant;

(v) Berger-Parker's evenness index $(B P)=1$ - $\left(N_{\max } / N\right)$, where $N_{\max }$ is the number of mycorrhizal tips of the most frequent ECM type and $N$ is the number of all mycorrhizal tips.

Data of two soil core samples were joint and single tree was used as a statistical unit. The Student $t$-test was used to test the significance of differences in the number of ECM types, vital ECM root tips, old, non-turgescent and non-mycorrhizal roots, total fine roots, percentage of vital root tips and abundance of exploration types between autumn and spring. In order to fit the normal distribution, data were transformed as follows: count data were transformed according to square root transformation (Bartlett 1936), while percentage values were transformed according to arcsine transformation using the Bliss formula (Snedecor \& Cochran 1976). The non-transformed data are presented in Tabs. 2 and 3. The Mann-Whitney $U$ test was used to test the significance of differences in diversity indexes. All statistical analyses were performed using the package STATISTICA ${ }^{\oplus}$ version 12 (StatSoft Inc., Tulsa, OK, USA).

\section{Results}

Overall, twenty ECM types were determined at the examined site in the two investigated seasons. Eleven types were identified to the species level, six to the genus level, while other three were determined to the family level or remained unidentified (Unknown type KR - Tab. 1). Cenococcum geophilum, Entoloma sp., Genea verrucosa, Inocybe maculata, Inocybe sp., Peziza sp., Sebacina incrustans, Tomentella sp. 2, Cortinariaceae sp., Tuber rufum and Tuber maculatum were recorded in both seasons. Hebeloma vaccinum, Inocybe cf. rimosa, Inocybe obsoleta, Thelephoraceae sp., and Tomentella sp. 1 were observed only in spring, while Clavulina sp., Hymenogaster tener, Inocybe cf. meliolens and Unknown type KR were recorded only in autumn (Fig. 1a, Fig. 1b).

No significant differences between seasons were found as for the number of ECM types, vital ECM roots, old, non-turgescent and non-mycorrhizal roots, total number of fine roots and percentage of vital ECM root tips. However, all values were higher in spring (Tab. 2).

There were no significant differences between seasons in species richness index, Shannon-Weaver's index, Evenness, Equitability and Berger-Parker's index (Tab. 2). Diversity indexes revealed that number of species, relative abundance of individual 
Fig. 1 - Ectomycorrhizal community structure in a mature white poplar stand in Serbia, based on sampling of 10 soil samples in spring (a) and 10 soil samples in autumn (b).

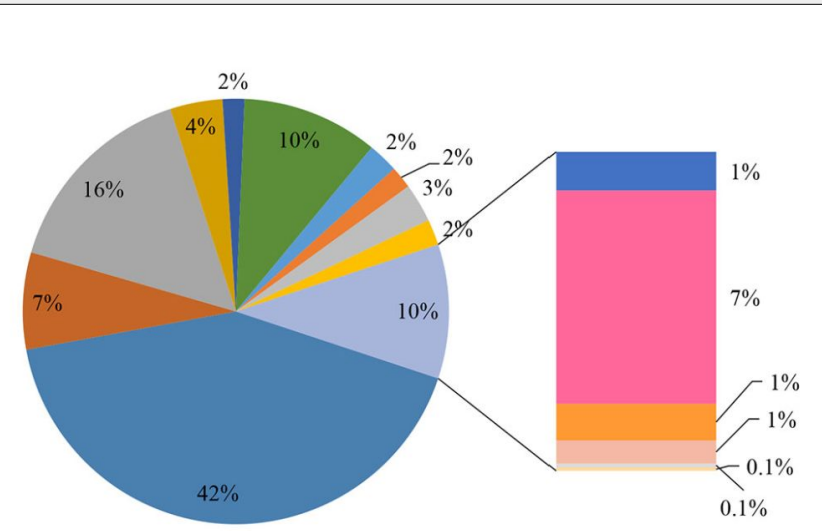

a) Spring

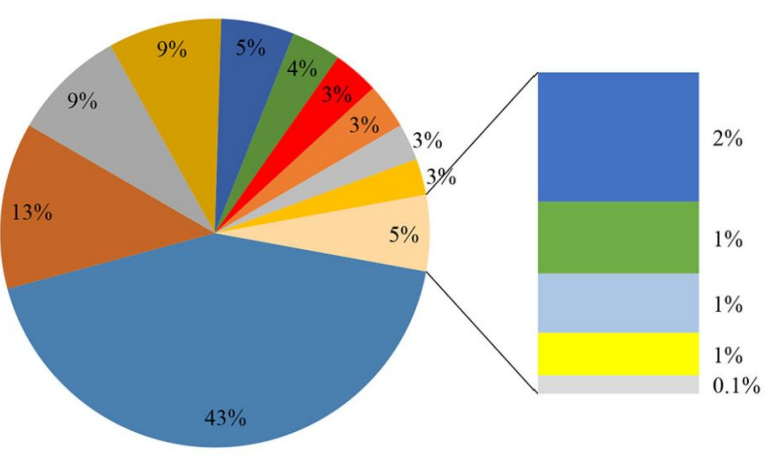

b) Autumn
Entoloma sp.

- Tuber maculatum

Tuber rufum

=Cenococcum geophilum

- Peziza sp.

Inocybe $\mathrm{sp}$.

Inocybe cf. rimosa

= Tomentella sp. 2

Genea verucosa

Inocybe maculata

- Sebacina incrustans

- Tomentella sp. 1

Cortinariaceae sp.

Thelephoraceae sp.

Hebeloma vaccinum

Inocybe obsoleta

- Entoloma sp.

- Tuber maculatum

- Tuber rufum

n Cenococcum geophilum

- Peziza sp.

- Inocybe sp.

- Inocybe cf. meliolens

$=$ Tomentella sp. 2

- Genea verucosa

- Inocybe maculata

- Sebacina incrustans

- Cortinariaceae sp.

Clavulina sp.

Unknown type KR

Hymenogaster tener

Fig. 2 - Relative abundance of ectomycorrhizal fungal families in a mature white poplar stand in Serbia, based on sampling of 10 soil samples in spring (a) and 10 soil samples in autumn (b)

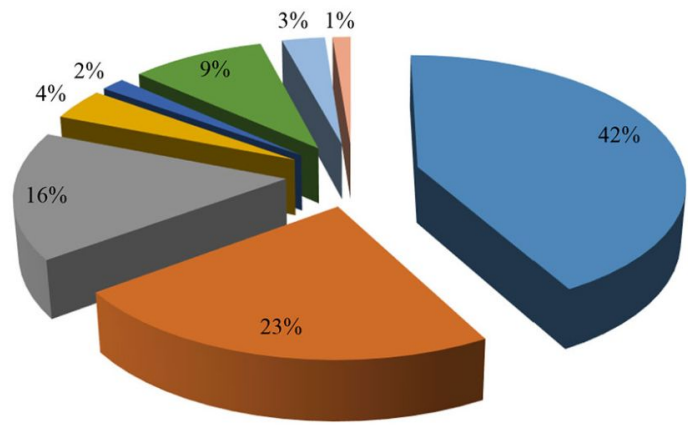

a) Spring

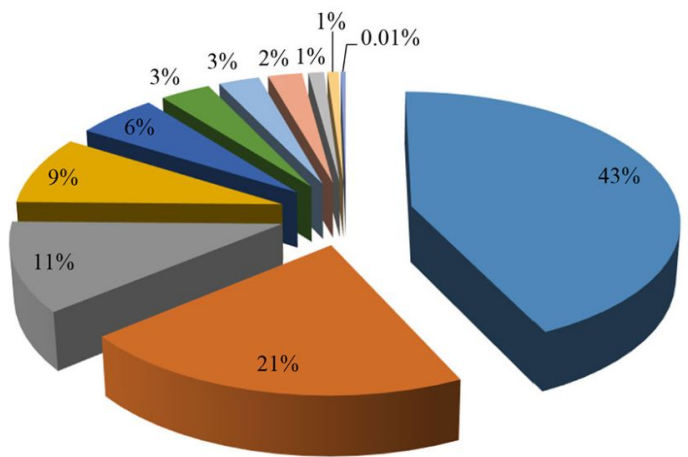

b) Autumn
Entolomataceae

- Tuberaceae

Cortinariaceae

- Cenococcum geophilum

- Pezizaceae

- Thelephoraceae

- Pyronamataceae

- Sebacinaceae

- Entolomataceae

- Tuberaceae

- Cortinariaceae

- Cenococcum geophilum

n Pezizaceae

- Thelephoraceae

- Pyronamataceae

Sebacinaceae

- Clavulinaceae

Unknown type

- Hymenogasteraceae 
Tab. 2 - Comparison of total and average values ( \pm standard erorr) of number of ectomycorrhizal (ECM) types, vital ECM root tips, old, non-turgescent and non-mycorrhizal roots (ONN), total fine roots and diversity indexes from a mature white stand located in Serbia between spring and autumn. (a): p-values after the t-test; (b): p-values after the Mann-Whitney's U test.

\begin{tabular}{|c|c|c|c|c|c|}
\hline \multirow[b]{2}{*}{ Parameter } & \multirow{2}{*}{$\begin{array}{l}\text { Spring } \\
\text { Total value } \\
\text { per site }\end{array}$} & \multicolumn{3}{|c|}{ Autumn } & \multirow[b]{2}{*}{$\mathrm{p}$-value } \\
\hline & & $\begin{array}{l}\text { Average value } \\
\text { per tree }\end{array}$ & $\begin{array}{l}\text { Total value } \\
\text { per site }\end{array}$ & $\begin{array}{l}\text { Average value } \\
\text { per tree }\end{array}$ & \\
\hline Number of ECM types & 16 & $5.10 \pm 0.60$ & 15 & $4.90 \pm 0.20$ & $0.838^{\mathrm{a}}$ \\
\hline Number of vital ECM root tips & 4300 & $430 \pm 133.6$ & 3030 & $303 \pm 65.5$ & $0.511^{\mathrm{a}}$ \\
\hline Number of ONN root tips & 22140 & $2214 \pm 511.6$ & 19335 & $1933.5 \pm 148.2$ & $0.686^{\mathrm{a}}$ \\
\hline Total number of fine root tips & 26440 & $2644 \pm 607.7$ & 22365 & $2236.5 \pm 141.9$ & $0.609^{a}$ \\
\hline$\%$ of vital ECM Root tips & 16 & $16.20 \pm 2.90$ & 14 & $13.90 \pm 3.10$ & $0.569^{a}$ \\
\hline Species richness index & 4.13 & $1.62 \pm 0.20$ & 4.02 & $1.63 \pm 0.08$ & $0.754^{\mathrm{b}}$ \\
\hline Shannon-Weaver index & 1.95 & $1.01 \pm 0.12$ & 2.00 & $1.15 \pm 0.06$ & $0.403^{b}$ \\
\hline Evenness & 0.70 & $0.626 \pm 0.06$ & 0.74 & $0.723 \pm 0.03$ & $0.174^{\mathrm{b}}$ \\
\hline Equitability & 1.62 & $1.44 \pm 0.13$ & 1.70 & $1.67 \pm 0.07$ & $0.174^{b}$ \\
\hline Berger-Parker index & 0.58 & $0.38 \pm 0.04$ & 0.57 & $0.48 \pm 0.04$ & $0.117^{\mathrm{b}}$ \\
\hline
\end{tabular}

species, equitability and evenness between species, and dominance rate of the most abundant species did not differ significantly between seasons, i.e., the ECM community structure did not change across seasons.

In both seasons, the same five ECM types dominated and represented about $80 \%$ of the total number of ECM root tips. The most abundant ECM type was Entoloma sp. with over $40 \%$, followed by Tuber maculatum, Cenococcum geophilum, Tuber rufum and Peziza sp. Relative abundance of these ECM types was similar in both seasons (Fig. 1a, Fig. 1b).

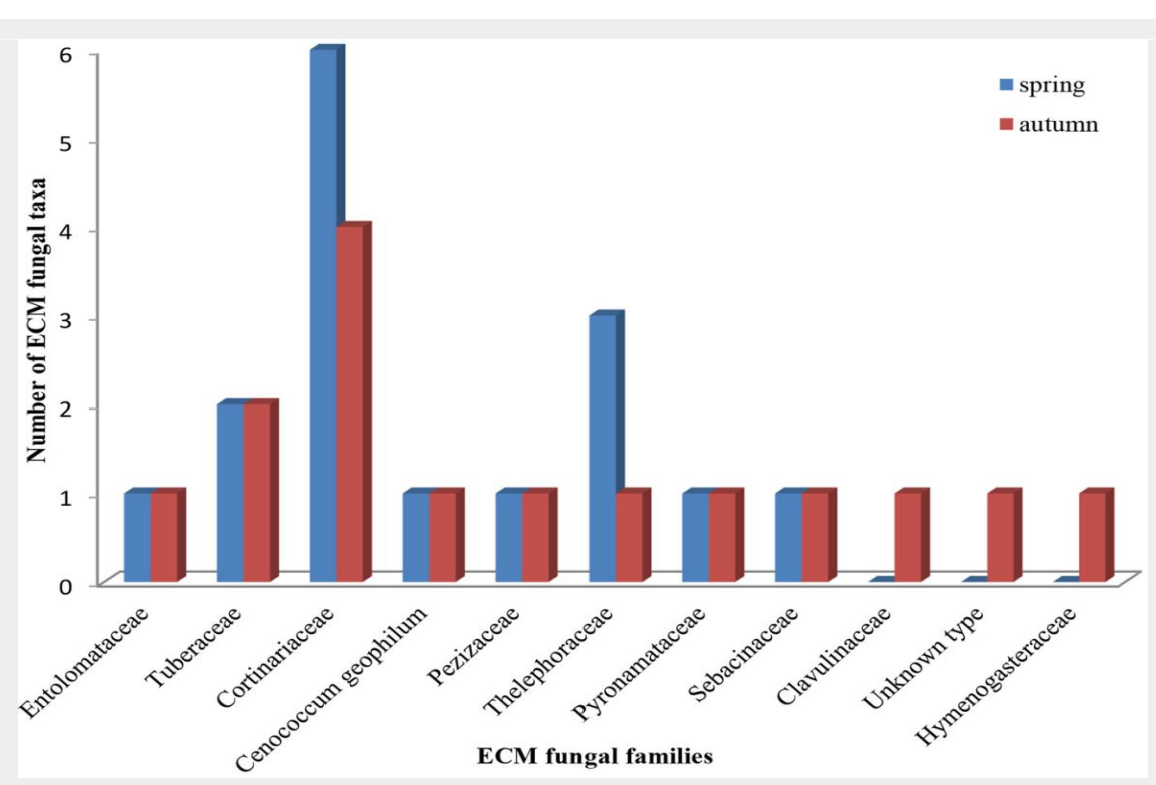

Fig. 3 - Number of ectomycorrhizal fungal taxa within fungal families recorded in mature white poplar stand located in Serbia in spring and autumn.

Tab. 3 - Relative abundance ( \pm standard error, \%) of ectomycorrhiza exploration types in a mature white poplar stand in Serbia in spring and autumn, and significance of Student $t$-test for the effect of season.

\begin{tabular}{lccc}
\hline Exploration type & Spring & Autumn & $t$-test (p-value) \\
\hline Contact type & $1.87 \pm 1.01$ & $2.59 \pm 2.59$ & 0.754 \\
Short distance & $65.23 \pm 9.38$ & $60.68 \pm 8.42$ & 0.648 \\
Medium distance & $32.90 \pm 9.09$ & $36.72 \pm 9.09$ & 0.724 \\
Long distance & 0 & 0 & - \\
\hline
\end{tabular}

higher than those colonized by Ascomycota fungi (in spring 68.5 vs. $31.5 \%$, respectively, in autumn 62 vs. $38 \%$, respectively data not shown).

The most abundant exploration type (ET) was short-distance ET followed by medium -distance ET and contact ET. Long-distance ET was not observed. Abundance of each ET did not significantly differ between the seasons (Tab. 3).

\section{Discussion}

The community of ectomycorrhizal fungi in this case study represented by a mature autochthonous white poplar stand located in the Special Nature Reserve "Kovilj-Petrovaradin marshes" (Serbia) is one of the few studies (Jakucs 2002, Katanić et al. 2010, Katanić 2014) on ECM diversity in white poplar and, up to our knowledge, the only one in a mature natural stand.

The average amount of vital ECM root tips $\left(1106 \mathrm{dm}^{-3}\right.$ in autumn and $1570 \mathrm{dm}^{-3}$ in spring) was considerably lower than in mature stands of other species such as beech (1460-15 $800 \mathrm{dm}^{-3}$ - Mašek \& Grebenc 2011) and spruce (4309-6716 $\mathrm{dm}^{-3}$ - Kraigher 1999). The number of all fine roots per soil volume in poplar stands was even more variable. In this study, such value was 9651 $\mathrm{dm}^{-3}$ in spring and $8163 \mathrm{dm}^{-3}$ in autumn, while ranged from $2599 \mathrm{dm}^{-3}$ in control plants irrigated with water to $4573 \mathrm{dm}^{-3}$ in plants treated with the anti-ozonant ethylenediurea in an ozone-sensitive clone (Katanić et al. 2014). Krpata et al. (2008) counted $17350-42630 \mathrm{dm}^{-3} \mathrm{ECM}$ root tips at a site with aspen contaminated by heavy metals. The relatively low number of ECM roots in our white poplar stand reflects the regular flooding occurring in the studied area and the dual colonization with ECM and $A M$ fungi. In the same poplar trees, Katanić et al. (2013) recorded values of root length colonization with ECM and AM fungi of 16.7 and $8.8 \%$, respectively.

The 20 ECM types recorded in total are a considerably lower number compared to some previous studies. On individual $\mathrm{Popu}-$ lus tremula trees in an old-growth mixed forest, Bahram et al. (2011) found 122 ECM fungal species. Analyzing ECM community 
at two sites with 30-40 $\mathrm{m}$ tall white poplars during three years, Jakucs (2002) recorded 70 ECM types, while Krpata et al. (2008) found 54 ECM types at a heavy metal polluted site with 20 to 25-year-old aspen trees. However, results of our research are in accordance with Visser et al. (1998), who recorded $22 \mathrm{ECM}$ types in a mixed forest dominated by American aspen, and Kaldorf et al. (2004), who observed 23 morphotypes in a five-year-old experimental aspen plantation. In addition, at three experimental sites with poplars Karlinski et al. (2013) found in total 27 ECM fungal taxa. In a white poplar plantation, Katanić et al. (2010) preliminary recorded 15 ECM types. However, when ECM diversity was studied seasonally, a total of 30 ECM types were observed (Katanić 2014). It seems that the number of ECM fine roots and the diversity of ECM types in poplar are highly variable, and the naturalness of the studied Special Nature Reserve does not contribute to increase ECM diversity as compared with other poplars' sites.

Values of Shannon-Weaver's diversity index (1.95 in spring and 2.00 in autumn) are in accordance with results obtained by DeBellis et al. (2006). These authors recorded a similar Shannon-Weaver diversity index of 2.00 in an aspen-dominated plot by using morphological characterization of ECM types, but a considerably higher index was recorded (3.00) when molecular identification tools were applied. Values of the Shannon-Weaver's diversity index obtained in extreme conditions are controversial. On the one hand, an ozone sensitive poplar clone showed lower values of ShannonWeaver's index, namely 1.60 in anti-ozonant protected plants and 1.21 in control plants (Katanić et al. 2014). On the other hand, Krpata et al. (2008) recorded relatively high value of Shannon-Weaver's diversity index (2.00) in aspen trees grown at a site contaminated with heavy metals. Due to the high variation of the ECM-based Shannon-Weaver's diversity index for poplar stands, and the fact that poplars form dual mycorrhizal association, this index can not be considered reliable for bioindication, as otherwise proven for spruce (Kraigher 1999). None of the above-mentioned authors compared fine roots data, species abundance or diversity indexes of poplar stands among seasons. However, in our study differences between seasons did not show any significant effect on diversity of the ECM community.

ECM community associated with white poplars in the Kovilj-Petrovaradin marshes consisted of few abundant and numerous infrequent ECM types, in accordance with previous research (De Roman \& De Miguel 2005, O'Hanlon \& Harrington 2012). Koide et al. (2007) reported abundant ECM types present in both seasons with similar relative abundance, while some rare species were specific for autumn or spring only. In both seasons, five ECM types made up near $80 \%$ of all ECM root tips, while 11 or 10
ECM types (in spring and autumn, respectively) contributed to the rest. This finding is in accordance with the evidence that the ECM community varied according to a logarithmic distribution of abundances (Dahlberg 2001, Pickles et al. 2010).

In the Kovilj-Petrovaradin marshes, the genus Inocybe was the most abundant one, with five ECM types, while genera Tuber and Tomentella had two members. Analyzing the diversity of mycorrhizal fungi in mixed deciduous stand, Lang et al. (2011) noticed that Tomentella and Inocybe were the most abundant and contributed mostly to the species richness. In the ECM community associated with aspen grown at the site contaminated with heavy metals, the most abundant taxonomic groups were Tomentella (17), Inocybe (6), Cortinarius (5), Hebeloma and Tuber with 3 operational taxonomic units (Krpata et al. 2008). At three sites with poplar clones, Karlinski et al. (2013) recorded the dominance of Cortinariaceae, Thelephoraceae and Tricholomataceae that constituted nearly $90 \%$ of the mycorrhizal community.

Inocybe species are well-known colonizers of ECM plants on disturbed or pioneer sites (Nara et al. 2003). Investigating mycorrhizal fungi associated with aspen at three different sites, Cripps (2003) observed 54 ECM fungi and 14 species belonged to the genus Inocybe. Tomenteloid fungi are the most frequent and widespread ECM partners of deciduous and evergreen tree species in the forests of Europe and North America (Gardes \& Bruns 1996, Dahlberg 2001). In the white poplar forest adapted to dry conditions of the Hungarian plain, Tomentella group was a minority component of the ECM community (Jakucs 2002). Similar observations were made in the occasionally flooded Kovilj-Petrovaradin marshes. Investigating the molecular diversity and the ecological specificity of truffles originating from the mid-west of Balkan Peninsula, Marjanović et al. (2010) recorded 12 species from this group, including Tuber rufum and T. maculatum. Cenococcum geophilum is a cosmopolitan ECM fungus with a wide range of hosts and habitats. It is a frequent and abundant ECM type adapted to environment under stress (LoBuglio 1999) that was recorded in almost half of the samples in our study. Di Pietro et al. (2007) noted that under extreme stress, ECM formed by Cenococcum geophilum has the ability to survive better than ECM of some other fungi, and that this species is particulary efficient in the protection of fine roots from drought stress. However, during the three-year survey of two ECM communities associated with poplars in dry conditions, Jakucs (2002) did not observe the presence of $C$. geophilum, while in our study it was found in an area that is occasionally flooded.

Although the differences were not statistically significant, all parameters investigated showed slightly higher values in spring than in autumn. This is in accor- dance with Courty et al. (2008) who recorded the highest number of vital ECM roots in April, while the lowest value was observed in September. The absence of significant differences between autumn and spring in the number of ECM types and diversity indexes in this study is in accordance with the results of De Roman \& De Miguel (2005). In both seasons the same three fungal families were the most abundant (Entolomataceae, Tuberaceae and Cortinariaceae). In contrast, Richard et al. (2011) found that the relative abundance of two out of three the most abundant families (Russulaceae and Cortinariaceae) showed significant seasonal shifts.

In both seasons, Basidiomycota dominated the examined ECM community, confirming numerous studies on poplars (Cripps 2001, 2003, Krpata et al. 2008, Karlinski et al. 2013, Katanić et al. 2014) where the Basidiomycota group was the most abundant and had more members in comparison to Ascomycota.

The most abundant exploration type in both seasons was short-distance ET and then medium-distance ET. Agerer (2001) found a relationship between ETs and their potential ecological roles. Jakucs (2002) noticed that in two forests adapted to similar ecological conditions, dominant ECM types belonged to the same ET. Analyzing ET of ECM community, Rudawska et al. (2011) concluded that abundance of a particular ET is related to the soil chemistry, since occurrence of contact ET was related to high nutrient content. On the other hand, medium-distance fringe exploration type was abundant at a sites contaminated with heavy metals (Rudawska et al. 2011, Karlinski et al. 2013). We assume that the similar distribution of ETs observed at our site in spring and autumn results from similar ecological conditions.

\section{Acknowledgements}

The study was co-financed by the Slovenian Research Agency through the Research Programme P4-0107 "Forest Biology, Ecology and Technology", through the Scholarship Ad futura (OMEGA D.O.O., for MK) and project III43007 "Studying climate change and its influence on the environment: impacts, adaptation and mitigation" financed by the Ministry of Education, Science and Technological Development of the Republic of Serbia within the framework of integrated and interdisciplinary research.

\section{References}

Abarenkov K, Nilsson RH, Larsson K-H, Alexander IJ, Eberhardt U, Erland S, Høiland K, Kjøller R, Larsson E, Pennanen T, Sen R, Taylor AFS, Tedersoo L, Ursing BM, Vrålstad T, Liimatainen K, Peintner U, Kõljalg U (2010). The UNITE database for molecular identification of fungi recent updates and future perspectives. New Phytologist 186 (2): 281-285. - doi: 10.1111/j.14698137.2009.03160.x

Agerer R (1991). Characterization of ectomycor- 
rhiza. In: "Methods in Microbiology", vol. 23 (Norris JR, Read DJ, Varma AK eds). Academic Press, London, UK, pp. 25-72.

Agerer R (2001). Exploration types of ectomycorrhizae. A proposal to classify ECM mycelial systems according to their patterns of differentiation and putative ecological importance. Mycorrhiza 11 (2): 107-114. - doi: 10.1007/s005720100 108

Agerer R (2008). Colour atlas of Ectomycorrhizae, $1^{\text {st }}-13^{\text {th }}$ delivery. Einhorn-VerlagEduard Dietenberger, Schwäbisch Gmünd, Germany.

Agerer R, Danielson RM, Egli S, Ingleby K, Luoma $D$, Treu R (2006). Descriptions of ectomycorrhizae, $1^{\text {st }}-10^{\text {th }}$ delivery. Einhorn-VerlagEduard Dietenberger, Schwäbisch Gmünd, Germany.

Agerer R, Rambold G (2014). DEEMY - An information system for characterization and determination of Ectomycorrhizae. Web site. [online] URL: http://www.deemy.de

Angelini P, Granetti B (1995). La micorrizazione di alcuni cloni micropropagati di Populus alba L. con Tuber magnatum Pico [ The mycorrhization of some micropropagated clones of Populus alba L. with Tuber magnatum Pico]. Plant Biosystems 129 (5-6): 1161-1177. [in Italian] - doi: 10.1080/11263509509436469

Atlas R, Bartha R (1981). Introduction to microbiology. Addison-Wesley Publishing Company, Reading, UK, pp. 242-244.

Bahram M, Põlme S, Kõljalg U, Tedersoo L (2011). A single aspen (Populus tremula) tree individual may potentially harbor dozens of Cenococcum geophilum ITS genotypes and hundreds of species of ectomycorrhizal fungi. FEMS Microbiological Ecology 75: 313-320. - doi: 10.1111/j.15 74-6941.2010.01000.x

Bartlett MS (1936). The square root transformation in analysis of variance. Journal of the Royal Statistical Society 3: 68-78. [online] URL: http:// www.jstor.org/stable/2983678

Courty PE, Frank A, Pierrat JC, Garbaye J (2008). Temporal changes in the ectomycorrhizal community in two soil horizons of a temperate oak forest. Applied and Environmental Microbiology 74 (18): 5792-5801. - doi: 10.1128/AEM.0159208

Cripps CL (2001). Mycorrhizal fungi of aspen forests: natural occurrence and potential application. In: "Sustaining Aspen in Western Landscapes: Symposium Proceedings" (Shepperd WD, Binkley D, Bartos D L, Stohlgren T J, Eskew LG eds). Report RMRS-P-18, Rocky Mountain Research Station, USDA Forest Service, Fort Collins, Colorado, USA, pp. 285-298. [online] URL: http://www.researchgate.net/profile/Tho mas_Stohlgren/publication/30068901

Cripps CL (2003). Native mycorrhizal fungi with aspen on smelter-impacted sites in the northern Rocky Mountains: occurrence and potential use in reclamation. In: Proceedings of the "National Meeting of the American Society of Mining and Reclamation and the $9^{\text {th }}$ Billings Land Reclamation Symposium". Society of Mined Land Reclamation, Lexington, KY, USA, pp. 193-208 [online] URL: http://www.plant sciences.montana.edu/facultyorstaff/faculty/cri pps/0193-Cripps.pdf

Dahlberg A (2001). Community ecology of ectomycorrhizal fungi: an advancing interdisciplinary field. New Phytologist 150: 555-562. - doi: 10.1046/j.1469-8137.2001.00142.x

De Roman M, De Miguel AM (2005). Post-fire, seasonal and annual dynamics of the ectomycorrhizal community in a Quercus ilex L. forest over a 3-year period. Mycorrhiza 15: 471-482. doi: 10.1007/s00572-005-0353-6

DeBellis T, Kernaghan G, Bradley R, Widden P (2006). Relationships between stand composition and ectomycorrhizal community structure in boreal mixed-wood forests. Microbial Ecology 52: 114-126. - doi: 10.1007/s00248-006-90388

Di Pietro M, Churin JL, Garbaye J (2007). Differential ability of ectomycorrhizas to survive drying. Mycorrhiza 17: 547-550. - doi: 10.1007/soo 572-007-0113-x

Eichhorn MP, Paris P, Herzog F, Incoll LD, Liagre F, Mantzanas K, Mayus M, Moreno G, Papanastasis VDJ, Pilbeam D, Pisanelli A, Dupraz C (2006). Silvoarable systems in Europe - past, present and future prospects. Agroforestry Systems 67 (1): 29-50. - doi: 10.1007/s10457-0051111-7

Gardes M, Bruns TD (1993). ITS primers with enhanced specificity for basidiomycetes - application to the identification of ectomycorrhizae and rusts. Molecular Ecology 2: 113-118. doi: 10.1111/j.1365-294X.1993.tbooo05.x

Gardes M, Bruns TD (1996). Community structure of ectomycorrhizal fungi in a Pinus muricata forest: above- and below-ground views. Canadian Journal of Botany 74: 1572-1583. - doi: 10.1139/b96-190

Jakucs E (2002). Ectomycorrhizae of Populus alba L. in south Hungary. Phyton 42: 199-210. [online] URL: http://www.zobodat.at/stable/ pdf/PHY_42_2_0199-0210.pdf

Kaldorf $\bar{M}$, Renker C, Fladung $M$, Buscot $F$ (2004). Characterization and spatial distribution of ectomycorrhizas colonizing aspen clones released in an experimental field. Mycorrhiza 14: 295-306. - doi: 10.1007/s00572-003-026 6-1

Karlinski L, Rudawska M, Leski T (2013). The influence of host genotype and soil conditions on ectomycorrhizal community of poplar clones. European Journal of Soil Biology 58: 51-58. doi: 10.1016/j.ejsobi.2013.05.007

Karlinski L, Rudawska M, Kieliszewska-Rokicka B, Leski T (2010). Relationship between genotype and soil environment during colonization of poplar roots by mycorrhizal and endophytic fungi. Mycorrhiza 20: 315-324. - doi: 10.1007/ s00572-009-0284-8

Katanić M, Orlović S, Grebenc T, Štupar B, Galić Z, Kovačević B, Kraigher H (2010). Identification of ectomycorrhizal types in a white poplar (Populus alba L.) plantation near Novi Sad. Les 62 (5): 155-159.

Katanić M, Kovačević B, Glowska N, Paoletti E, Vasić S, Matavulj M, Kraigher H (2013). Colonization of poplar roots with ectomycorrhizal, arbuscular mycorrhizal and dark septated endophytic fungi. Topola 191/192: 17-29. [in Serbian with English summary]

Katanić M (2014). Diversity of mycorrhizal fungi of poplars (Populus spp). PhD thesis, Faculty of Sciences, University of Novi Sad, Novi Sad, Serbia, pp. 194. [in Serbian with English summary] Katanić M, Paoletti E, Orlovi S, Grebenc T, Kraigher $H$ (2014). Mycorrhizal status of an ozone sensitive poplar clone treated with the antiozonant ethylenediurea. European Journal of Forest Research 133 (4): 735-743. - doi: $10.1007 /$ s10342-013-0751-9

Klašnja B, Orlović S, Galić Z, Drekić M (2006). Poplar biomass of short rotation plantations as renewable energy raw material. In: "Biomass and bioenergy new research" (Columbus F ed). Nova Science Publishers, New York, USA, pp. 35-66.

Klopfenstein NB, Chun YW, Kim MS, Ahuja MR, Dillon MC, Carman RC, Eskew LG (1997). Micropropagation, genetic engineering, and molecular biology of Populus. General Technical Report, Rocky Mountain Forest and Range Experiment Station, USDA Forest Service, Fort Collins, CO, USA, pp. 326. [online] URL: http:// www.cabdirect.org/abstracts/19981606652.ht $\mathrm{ml}$

Koide RT, Shumway DL, Xu B, Sharda JN (2007). On temporal partitioning of a community of ectomycorrhizal fungi. New Phytologist 174: 420-429. - doi: 10.1111/j.1469-8137.2007.02000.x

Kõljalg U, Nilsson RH, Abarenkov K, Tedersoo L, Taylor AFS, Bahram M, Bates ST, Bruns TT, Bengtsson-Palme J, Callaghan TM, Douglas B, Drenkhan T, Eberhardt U, Dueñas M, Grebenc T, Griffith GW, Hartmann M, Kirk PM, Kohout P, Larsson E, Lindahl BD, Lücking R, Martín MP, Matheny PB, Nguyen NH, Niskanen T, Oja J, Peay KG, Peintner U, Peterson M, Põldmaa K, Saag L, Saar I, Schüßler A, Senés C, Smith ME, Suija A, Taylor DE, Telleria MT, Weiß M, Larsson KH (2013). Towards a unified paradigm for sequence-based identification of fungi. Molecular Ecology 22: 5271-5277. - doi: 10.1111/mec.12481 Kraigher H (1996). Types of ectomycorrhizae their taxonomy, role and application. Zbornik Gozdarstva in Lesarstva 49: 33-66. [in Slovenian with English summary]

Kraigher H (1999). Diversity of types of ectomycorrhizae on Norway spruce in Slovenia. Phyton 39 (3): 199-202. [online] URL: http://www.zobo dat.at/stable/pdf/PHY_39_3_0199-0202.pdf Kraigher H, Al Sayegh-Petkovšek S, Grebenc T, Simončič $P$ (2007). Types of ectomycorrhiza as pollution stress indicators: case studies in Slovenia. Environmental Monitoring and Assessment 128 (1): 31-45. - doi: 10.1007/s10661-0069413-4

Krpata D, Peintner U, Langer I, Walter JF, Schweiger P (2008). Ectomycorrhizal communities associated with Populus tremula growing on a heavy metal contaminated site. Mycological Research 112 (9): 1069-1079. - doi: 10.1016/ j.mycres.2008.02.004

Lang C, Seven J, Polle A (2011). Ectomycorrhizal fungal diversity, tree diversity and root nutrient relations in a mixed Central European forest. Mycorrhiza 21: 297-308. - doi: 10.1007/s00572010-0338-y

LoBuglio KF (1999). Cenococcum. In: "Ectomycorrhizal fungi key genera in profile”. Springer, Berlin, Heidelberg, Germany, pp. 287-309. - doi: 10.1007/978-3-662-06827-4_12

Marjanović Z, Grebenc T, Marković M, Glišić A, Milenković M (2010). Molecular diversity and ecological specificity of truffles (genus Tuber) originating from mid-west of the Balkan Peninsula. Sydowia 62 (1): 67-87. [online] URL: http://eprints.gozdis.si/1137/1/ 
Mašek A, Grebenc T (2011). Beech (Fagus sylvatica L.) ectomycorrhiza and fine roots in mature forests, regeneration stands and on seedlings. Les 63 (5): 192-196. [in Slovenian with English summary]

Molina R, Massicotte H, Trappe JM (1992). Specificity phenomena in mycorrhizal symbiosys: community-ecological consequences and practical implications. In: “Mycorrhizal functioning: an integrative plant-fungal process" (Allen MF ed). Chapman and Hall, New York, USA, pp. 357-423. [online] URL: http://books.google. com/books?id=Sf8bAgJRBWMC

Nara K, Nakaya H, Hogetsu T (2003). Ectomycorrhizal sporocarp succession and production during early primary succession on Mount Fuji. New Phytologist 158: 193-206. - doi: 10.1046/j.14 69-8137.2003.00724.x

Neville J, Tessier JL, Morrison I, Scarratt J, Canning B, Klironomos JN (2002). Soil depth distribution of ecto- and arbuscular mycorrhizal fungi associated with Populus tremuloides within a 3-year-old boreal forest clear-cut. Applied Soil Ecology 19: 209-216. - doi: 10.1016/So929-1393 (01)00193-7

Newman LA, Strand SE, Choe N, Duffy J, Ekuan G, Ruszaj M, Shurleff BB, Wilmoth J, Heilman P, Gordon MP (1997). Uptake and biotransformation of trichloroethylene by hybrid poplars.
Environment, Science and Technology 31: 10621067. - doi: 10.1021/es960564W

O'Hanlon R, Harrington TJ (2012). Similar taxonomic richness but different communities of ectomycorrhizas in native forests and non-native plantation forests. Mycorrhiza 22: 371-382. doi: 10.1007/s00572-011-0412-0

Pickles BJ, Genney DR, Potts JM, Lennon JJ, Anderson IC, Alexander IJ (2010). Spatial and temporal ecology of Scots pine ectomycorrhizas. New Phytologist 186: 755-768. - doi: 10.1111/ j.1469-8137.2010.03204.x

Quoreshi AM (2008). The use of mycorrhizal biotechnology in reforestation of disturbed ecosystem. In: "Mycorrhizae: Sustainable Agriculture and Forestry". Springer, The Netherlands, pp. 303-320. - doi: 10.1007/978-1-40208770-7 13

Richard F, Roy M, Shahin O, Sthultz C, Duchemin $M$, Joffre R, Selosse M-A (2011). Ectomycorrhizal communities in a Mediterranean forest ecosystem dominated by Quercus ilex: seasonal dynamics and response to drought in the surface organic horizon. Annals of Forest Science 68: 57-68. - doi: 10.1007/s13595-010-0007-5

Rudawska M, Leski T, Stasinska M. (2011). Species and functional diversity of ectomycorrhizal fungal communities on Scots pine (Pinus sylvestris L.) trees on three different sites. An- nals of Forest Science 68: 5-15. - doi: $10.1007 /$ s13595-010-0002-x

Smith SE, Read DJ (2008). Mycorrhizal symbiosis ( $3^{\text {rd }}$ edn). Elsevier-Academic Press, London, UK, pp. 787.

Snedecor W, Cochran WG (1976). Statistical methods ( $6^{\text {th }}$ edn). The lowa State University Press, Ames, lowa, USA, pp. 503.

Stanojević G (2012). Analysis of annual sums of precipitation in Serbia. Journal of Geographical Institute Jovan Cvijić 62 (2): 1-13. - doi: 10.2298/ IJGI1202001S

Taylor AFS, Martin F, Read DJ (2000). Fungal diversity in ectomycorrhizal communities of Norway spruce (Picea abies (L.) Karst.) and beech (Fagus sylvatica L.) along north-south transects in Europe. In: "Carbon and nitrogen cycling in European forest ecosystems" (Schulze E-D ed). Ecological Studies 142, Springer-Verlag, Berlin-Heidelberg, Germany, pp. 343-365. doi: 10.1007/978-3-642-57219-7_16

Visser S, Maynard D, Danieson RM (1998). Response of ecto- and arbuscular fungi to clearcutting and the application of chipped aspen wood in a mixedwood site in Alberta, Canada. Applied Soil Ecology 7: 257-269. - doi: 10.1016/ So929-1393(97)00060-7 